\title{
Pseudomonas pelagia sp. nov., isolated from a culture of the Antarctic green alga Pyramimonas gelidicola
}

Correspondence Byung Cheol Cho bccho@snu.ac.kr

\author{
Chung Yeon Hwang, ${ }^{1}$ Gwang II Zhang, ${ }^{1}$ Sung-Ho Kang, ${ }^{2}$ Hak Jun Kim ${ }^{2}$ \\ and Byung Cheol Cho ${ }^{1}$
}
${ }^{1}$ School of Earth and Environmental Sciences and Research Institute of Oceanography, Seoul National University, 599 Gwanak-ro, Gwanak-gu, Seoul 151-742, Republic of Korea
${ }^{2}$ Division of Polar Biology and Ocean Sciences, Korea Polar Research Institute, Get-Pearl Tower, Songdo Technopark, 7-50 Songdo-dong, Yeonsu-gu, Incheon 406-840, Republic of Korea

Two Gram-negative, strictly aerobic bacterial strains, designated CL-AP6 ${ }^{\top}$ and CL-AP22, were isolated from a culture of a green alga, Pyramimonas gelidicola, established from the Antarctic. Cells of the strains were straight rods and motile by means of a single polar flagellum. The strains grew with $0.5-8 \%(\mathrm{w} / \mathrm{v}) \mathrm{NaCl}$ (optimum, $1-2 \%$ ) and at $4-33^{\circ} \mathrm{C}$ (optimum, $25{ }^{\circ} \mathrm{C}$ ) and $\mathrm{pH} 6.5-$ 9.1 (optimum, $\mathrm{pH}$ 7.5-8.1). The two strains shared $98.8 \% 16 \mathrm{~S}$ rRNA gene sequence similarity. Analysis of the $16 \mathrm{~S}$ rRNA gene sequences of strains $\mathrm{CL}^{-A P 6}{ }^{\top}$ and CL-AP22 revealed that they were members of the genus Pseudomonas and were most closely related to Pseudomonas xiamenensis $\mathrm{C} 10-2^{\top}$ (95.5-95.8\% sequence similarity) and next to Pseudomonas pertucinogena NBRC $14163^{\top}$ (95.1-95.5\% sequence similarity) and to other members of the genus Pseudomonas ( $<95.2 \%$ sequence similarity). Phylogenetic analyses based on the $16 \mathrm{~S}$ rRNA gene sequences showed that strain $\mathrm{CL}^{-A P 6}{ }^{\top}$ formed a robust clade with strain CL-AP22, and that this clade clustered tightly with the nearest clade containing $P$. xiamenensis and $P$. pertucinogena. The major isoprenoid quinone of strains $\mathrm{CL}-\mathrm{AP} 6^{\top}$ and CL-AP22 was Q-9 and the major cellular fatty acids were $\mathrm{C}_{18: 1} \omega 7 c(40.2-41.6 \%)$, summed feature $3\left(\mathrm{C}_{16: 1} \omega 7 c\right.$ and/or iso- $\left.\mathrm{C}_{15: 0} 2-\mathrm{OH} ; 26.3-26.8 \%\right), \mathrm{C}_{16: 0}(13.7-13.9 \%)$ and $\mathrm{C}_{12: 0}(5.8-6.2 \%)$. The genomic DNA $\mathrm{G}+\mathrm{C}$ contents of strains CL-AP6 ${ }^{\top}$ and CL-AP22 were 59.1 and $57.2 \mathrm{~mol} \%$, respectively. DNADNA hybridization experiments revealed high relatedness values (98.5 $\pm 0.5 \%$; mean \pm SEM, $n=2$ ) between strains CL-AP6 ${ }^{\top}$ and CL-AP22, indicating that the two strains constituted a single species. However, the two strains differed phenotypically from $P$. xiamenensis by their inability to grow without $\mathrm{NaCl}$, temperature range for growth, hydrolysis of starch and production of certain enzymes. The phylogenetic analysis and physiological and biochemical data showed that strains $\mathrm{CL}-A P 6^{\top}$ and CL-AP22 should be classified as representing a novel species in the genus Pseudomonas, for which the name Pseudomonas pelagia sp. nov. is proposed. The type strain is

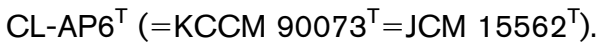

Since the genus Pseudomonas was proposed by Migula (1894), members of novel Pseudomonas species have been isolated from many natural materials including soil, fresh and saline waters, plants and clinical specimens (Palleroni, 2005). Because of its broad phenotypic definition (i.e.

The GenBank/EMBL/DDBJ accession numbers for the 16S rRNA gene sequences of strains CL-AP6 $^{\top}$ and CL-AP22 are EU888911 and FJ687951, respectively.

An extended neighbour-joining tree based on 16S rRNA gene sequences showing the positions of strains $\mathrm{CL}^{-A P 6^{\top}}$ and $\mathrm{CL}-\mathrm{AP} 22$ and related Pseudomonas species, and a transmission electron micrograph of a negatively stained cell of strain CL-AP6 $^{\top}$ are available as supplementary material with the online version of this paper. polarly flagellated, Gram-negative, rod-shaped, aerobic bacteria; Palleroni, 1984), the genus Pseudomonas is an extensively heterogeneous group (Gupta et al., 2008). The genus has been divided into distinct groups several times on the basis of phenotypic features (Sneath et al., 1981), DNA-DNA hybridization (Palleroni, 1984), chemotaxonomic data (Oyaizu \& Komagata, 1983) and 16S rRNA gene sequence similarity (Anzai et al., 2000). In Bergey's Manual of Systematic Bacteriology (Palleroni, 2005), 53 species and 8 putative species of the genus Pseudomonas have been described. Thereafter, about 60 species of the genus Pseudomonas were discovered. Based on 16S rRNA gene sequences, the genus appears to consist of two major 
clusters (Anzai et al., 2000). The vast majority (>95\%) of recognized species or subspecies of the genus Pseudomonas are included in one of the two major clusters. In the other cluster, the Pseudomonas pertucinogena group includes only two species with validly published names; Pseudomonas pertucinogena (Kawai \& Yabuuchi, 1975) and Pseudomonas xiamenensis (Lai \& Shao, 2008). In the present study, two strains affiliated with the $P$. pertucinogena group were isolated from a culture of an Antarctic green alga and subjected to a polyphasic taxonomic analysis.

A culture of the green alga Pyramimonas gelidicola (Korea Polar Research Institute, KOPRI Culture Collection of Polar Micro-organism, KCCPM strain no. AnM0046) was established from the Antarctic Ocean in 1981. It was maintained by transferring small quantities of the culture to fresh $\mathrm{f} / 2$ medium (Guillard \& Ryther, 1962) once a month. The culture was incubated at $2-4{ }^{\circ} \mathrm{C}$ under continuous light conditions. For the isolation of psychrophilic or psychrotolerant bacteria, an aliquot $(10 \mu \mathrm{l})$ of the culture was spread on two marine agar 2216 (MA; Difco) plates in a cold room $\left(4{ }^{\circ} \mathrm{C}\right)$. The plates were incubated aerobically at $4{ }^{\circ} \mathrm{C}$ in the light for 2 weeks. Strain CL-AP6 ${ }^{\mathrm{T}}$ was isolated and subsequently streaked onto fresh MA at $4{ }^{\circ} \mathrm{C}$. The purification procedure was repeated four times. Strain CL-AP22 (=KCCM 90081) was isolated from the same culture of Pyramimonas gelidicola using the above isolation and purification procedure on a different day. The strains were maintained both on MA at $4{ }^{\circ} \mathrm{C}$ and in marine broth 2216 (MB; Difco) supplemented with $30 \%$ $(\mathrm{v} / \mathrm{v})$ glycerol at $-80{ }^{\circ} \mathrm{C}$.

For 16S rRNA gene amplification by PCR, DNA was extracted from a single colony by using a boiling method (Englen \& Kelley, 2000). The crude extracts served as the DNA template for PCR, which included Taq DNA polymerase (Bioneer) and primers $27 \mathrm{~F}$ and $1492 \mathrm{R}$ (Lane, 1991). The PCR product was purified by using an AccuPrep PCR purification kit (Bioneer) and direct sequence determination of the purified 16S rRNA gene was performed using sequencing primers $(27 \mathrm{~F}, 518 \mathrm{~F}, 800 \mathrm{R}$ and 1492R; Lane, 1991; Anzai et al., 1997) with an Applied Biosystems automated sequencer (ABI3730XL) at Macrogen, Seoul, Korea. Almost-complete 16S rRNA gene sequences of strains CL-AP6 ${ }^{\mathrm{T}}$ (1460 bp) and CL-AP22 (1415 bp) were obtained and compared with 16S rRNA gene sequences available in GenBank using BLASTN searches (Altschul et al., 1990). The sequences of strains CL-AP6 ${ }^{\mathrm{T}}$ and CL-AP22 were aligned with sequences from the type strains of some Pseudomonas species, obtained from GenBank and Ribosomal Database Project II (Cole et al., 2007) databases, using known $16 \mathrm{~S}$ rRNA gene secondarystructure information. Phylogenetic trees were obtained by using the neighbour-joining (Saitou \& Nei, 1987), maximum-parsimony (Fitch, 1971) and maximum-likelihood (Felsenstein, 1981) methods. An evolutionary distance matrix for the neighbour-joining method was generated according to the model of Jukes \& Cantor (1969). The robustness of the tree topologies was assessed by bootstrap analyses based on 1000 replications for neighbour-joining and maximum-parsimony methods. Alignment analysis was carried out using the jPHYDIT program (Jeon et al., 2005) and phylogenetic analyses were carried out using MEGA 4 (Tamura et al., 2007) and PAUP 4.0 (Swofford, 1998). Likelihood parameters were estimated by using the hierarchical ratio test in MODELTEST, version 3.04 (Posada \& Crandall, 1998) and bootstrap analysis based on 100 replications was conducted. The DNA-DNA relatedness between strains CL-AP6 ${ }^{\mathrm{T}}$ and CLAP22 was determined by using dot-blot hybridization as described by Choi et al. (2006). The experiment was repeated on different days.

Analysis of the 16S rRNA gene sequences of strains CL$\mathrm{AP}^{\mathrm{T}}$ and CL-AP22 revealed that they shared 98.8\% similarity. They were most closely related to $P$. xiamenensis C10-2 ${ }^{\mathrm{T}}$ (95.5-95.8\% sequence similarity) and next to $P$. pertucinogena NBRC $14163^{\mathrm{T}}$ (95.1-95.5\% sequence similarity). The sequence similarities of the two strains to other recognized species of the genus Pseudomonas were below $95.2 \%$. Phylogenetic analyses based on $16 \mathrm{~S}$ rRNA gene sequences showed that strains CL-AP6 ${ }^{\mathrm{T}}$ and CL-AP22 belonged to the genus Pseudomonas (Fig. 1). In addition, strain CL-AP6 ${ }^{\mathrm{T}}$ formed a robust clade with strain CLAP22, and this clade clustered tightly with the nearest clade comprising $P$. xiamenensis and $P$. pertucinogena (Fig. 1). This grouping was supported by high bootstrap values (neighbour-joining, $99 \%$; maximum-likelihood, $91 \%$; and maximum-parsimony, $93 \%)$. DNA-DNA hybridization experiments revealed high relatedness values $(98.5 \pm$ $0.5 \%$; mean \pm SEM, $n=2$ ) between strains CL-AP6 ${ }^{\mathrm{T}}$ and CL-AP22, indicating that they belonged to the same species. Thus, the low similarity value (i.e. $<96 \%$ ) with recognized Pseudomonas species and the phylogenetic positions of strains CL-AP6 ${ }^{\mathrm{T}}$ and CL-AP22 indicated that they represent a novel species of the genus Pseudomonas.

Growth rates (approximately $2.4 \mathrm{~d}^{-1}$ ) of strains CL-AP6 ${ }^{\mathrm{T}}$ and CL-AP22 in Luria-Bertani broth (LB; Sambrook \& Russell, 2001) at $25^{\circ} \mathrm{C}$ were comparable to those in $\mathrm{MB}$ at $25^{\circ} \mathrm{C}$ (data not shown). In addition, both strains grew well on LB agar as well as on MA. Unless otherwise specified, all tested physiological and biochemical characteristics of the two strains were based on cultures grown on LB agar at $25{ }^{\circ} \mathrm{C}$ with $P$. xiamenensis JCM $13530^{\mathrm{T}}$ and $P$. pertucinogena JCM $11590^{\mathrm{T}}$ as reference strains, except for susceptibility to antibiotics, and fatty acid and quinone analyses. Morphological and physiological analyses were performed as follows. Gram-staining was performed as described by Smibert \& Krieg (1994). Motility of the cells was observed by using the hanging drop method (Skerman, 1967). Cell morphology and the presence of flagella were observed using transmission electron microscopy (EX2; JEOL). Anaerobic growth was checked on LB agar and a modified ZOF medium (per litre distilled water: tryptone, $10 \mathrm{~g}$; yeast extract, $5 \mathrm{~g}$; glucose, $10 \mathrm{~g}$; phenol red, $10 \mathrm{mg}$; Bacto agar, $15 \mathrm{~g}$; Lemos et al., 1985) by using the GasPak anaerobic system (BBL) for 15 days. Poly- $\beta$-hydroxybutyrate gran- 


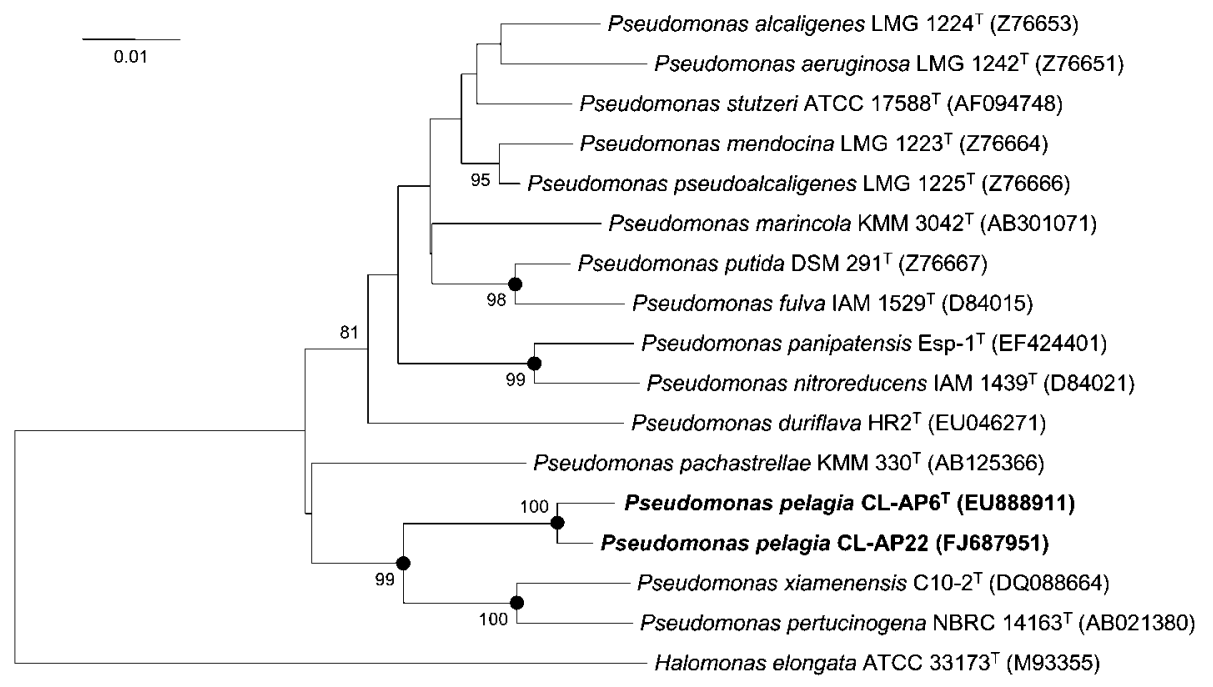

Fig. 1. Neighbour-joining tree showing the phylogenetic positions of strains CL-AP6 ${ }^{\top}, C L-A P 22$ and type strains of some related Pseudomonas species based on 16S rRNA gene sequences. Only bootstrap values above $70 \%$ are shown (1000 resamplings) at branch points. Solid circles indicate that the corresponding nodes were also obtained in maximum-likelihood and maximum-parsimony trees. Halomonas elongata was used as an outgroup. Bar, 0.01 nucleotide substitutions per site. The full version of this phylogenetic tree is available as Supplementary Fig. S1 (in IJSEM Online).

ules were observed by using epifluorescence microscopy (BX60; Olympus) after Nile blue A staining (Ostle \& Holt, 1982). Endospores were detected by using malachite green staining (Smibert \& Krieg, 1994). The formation of fluorescent pigments was tested on King's medium B (King et al., 1954) with Pseudomonas koreensis KACC $10848^{\mathrm{T}}$ and Pseudomonas jinjuensis KACC $10760^{\mathrm{T}}$ as a positive and a negative strain, respectively (Kwon et al., 2003). The temperature range for growth was determined on the basis of colony formation on LB agar incubated at temperatures ranging from 5 to $40{ }^{\circ} \mathrm{C}$ (increments of $5{ }^{\circ} \mathrm{C}$ ) and 4,33 and $37^{\circ} \mathrm{C}$. The $\mathrm{pH}$ range $(\mathrm{pH} 5.1-10.2 ; \mathrm{pH}$ 5.1, $5.9,6.5,7.2,7.5,8.1,8.4,9.1,9.6$ and 10.2) for growth was determined by assessing changes in $\mathrm{OD}_{600}$ over the incubation period (up to 7 days) in LB broth at $25^{\circ} \mathrm{C}$. Prior to autoclaving, the $\mathrm{pH}(5-10$, in increments of $0.5 \mathrm{pH}$ units) was adjusted using $1 \mathrm{M} \mathrm{NaOH}$ and $1 \mathrm{M} \mathrm{HCl}$ solutions. After autoclaving and cooling, the $\mathrm{pH}$ values for the subsamples of each medium were measured, before the inoculation of cells. The tolerance of $\mathrm{NaCl}$ was determined by assessing changes in $\mathrm{OD}_{600}$ in $\mathrm{LB}$ medium supplemented with $\mathrm{NaCl}$ concentrations of $0,0.5,1,2,3,4,5,6,7,8$, 9,10 and $12 \%(\mathrm{w} / \mathrm{v})$ at $25^{\circ} \mathrm{C}$.

Cells of strains CL-AP6 ${ }^{\mathrm{T}}$ and CL-AP22 were Gramnegative, strictly aerobic and motile by means of a single polar flagellum (Supplementary Fig. S2, available in IJSEM Online). Strains CL-AP6 ${ }^{\mathrm{T}}$ and CL-AP22 could be differentiated from the phylogenetically closely related species (i.e. P. xiamenensis JCM $13530^{\mathrm{T}}$ and P. pertucinogena JCM $11590^{\mathrm{T}}$ ) by their ability to grow at $4{ }^{\circ} \mathrm{C}$ and their inability to grow at $37{ }^{\circ} \mathrm{C}$ (Table 1 ). In addition, the two strains were not able to grow without $\mathrm{NaCl}$, whereas $P$. xiamenensis JCM $13530^{\mathrm{T}}$ and $P$. pertucinogena JCM $11590^{\mathrm{T}}$ were able to grow without $\mathrm{NaCl}$ (Table 1). The results of the other physiological and biochemical tests are given in the species description and in Table 1.

Catalase and oxidase activities and $\mathrm{H}_{2} \mathrm{~S}$ production were assayed according to the protocols described by Smibert \& Krieg (1994). Amylase, gelatinase, nitrate reductase activities and degradation of Tweens 20,40, 60 and 80, and Voges-Proskauer and methyl red tests were determined according to Hansen \& Sørheim (1991) using LB instead of $\mathrm{MB}$ as growth medium. Other enzyme activities were assayed using the API ZYM and API 20NE kits (bioMérieux) according to the manufacturer's instructions. To examine sole carbon utilization, a basal broth medium with the $\mathrm{NaCl}$ concentration adjusted to $1 \%$ (Liu \& Shao, 2005) containing $0.1 \%$ carbon source was used. Growth was monitored by $\mathrm{OD}_{600}$ using a spectrophotometer (Ultraspec 2000; Pharmacia Biotech). OD $_{600}$ was measured for 20 days. Carbon utilization was scored as negative when growth rate was equal to, or less than that in the negative control with no carbon source. Growth rate was measured by assessing changes in $\mathrm{OD}_{600}$. Resistance to antibiotics was determined by using the disc diffusion plate method (Bauer et al., 1966).

Strains CL-AP6 ${ }^{\mathrm{T}}$ and CL-AP22 showed almost identical results for phenotypic characteristics except that naphtholAS-BI-phosphohydrolase activity was present in strain CL$\mathrm{AP}^{\mathrm{T}}$ but not in strain CL-AP22 (Table 1). Strains CL$\mathrm{AP}^{\mathrm{T}}$ and CL-AP22 could be distinguished from $P$. xiamenensis and $P$. pertucinogena by means of the following traits: the ability to hydrolyse starch and the presence of 
Table 1. Differential characteristics of strains $C L-A P 6^{\top}$ and CL-AP22 and other phylogenetically related Pseudomonas species

Taxa: 1, strains CL-AP6 ${ }^{\mathrm{T}}$ and CL-AP22 (data from this study); 2, P. xiamenensis C10-2 ${ }^{\mathrm{T}}$ (Lai \& Shao, 2008); $3, P$. pertucinogena ATCC $190^{\mathrm{T}}$ (Kawai \& Yabuuchi, 1975). +, Positive; -, negative; w, weakly positive.

\begin{tabular}{|c|c|c|c|}
\hline Characteristic & $1^{*}$ & 2 & 3 \\
\hline Cell size $(\mu \mathrm{m})$ & $0.4-0.5 \times 1.8-2.0$ & $0.6-0.8 \times 1.1-1.3$ & $0.4 \times 1.1$ \\
\hline \multicolumn{4}{|l|}{ Growth at: } \\
\hline $4^{\circ} \mathrm{C}$ & + & - & $-\dagger$ \\
\hline $37^{\circ} \mathrm{C}$ & - & + & + \\
\hline $\mathrm{NaCl}$ range for growth (\%) & $0.5-8$ & $0-8$ & $0-5 \ddagger$ \\
\hline $\mathrm{NaCl}$ range for optimal growth (\%) & $1-2$ & $1-3$ & 3 \\
\hline Nitrate reduction & + & + & - \\
\hline \multicolumn{4}{|l|}{ Hydrolysis of: } \\
\hline Starch & + & - & - \\
\hline Tween 80 & - & + & - \\
\hline \multicolumn{4}{|l|}{$\mathrm{API} Z \mathrm{ZYM} \dagger$} \\
\hline$N$-Acetyl- $\beta$-glucosaminidase & - & + & - \\
\hline Acid phosphatase & $+(\mathrm{w})$ & $\mathrm{W}$ & - \\
\hline Alkaline phosphatase & $+(\mathrm{w})$ & $\mathrm{W}$ & - \\
\hline$\alpha$-Chymotrypsin & - & + & - \\
\hline Esterase (C4) & $+(\mathrm{w})$ & - & - \\
\hline Esterase lipase (C8) & $+(\mathrm{w})$ & + & - \\
\hline$\beta$-Galactosidase & - & + & - \\
\hline Lipase (C14) & $+(\mathrm{w})$ & - & - \\
\hline Naphthol-AS-BI-phosphohydrolase & $+(-)$ & + & - \\
\hline Trypsin & - & + & - \\
\hline Valine arylamidase & - & + & - \\
\hline \multicolumn{4}{|l|}{ Utilization of sole carbon source } \\
\hline Citrate & - & + & $-\ddagger$ \\
\hline Ethanol & - & + & - \\
\hline Succinate & - & - & + \\
\hline DNA G $+C$ content $(\mathrm{mol} \%)$ & $59.1(57.2)$ & 61.2 & 60.0 \\
\hline
\end{tabular}

${ }^{\star}$ Differential data for strain CL-AP22 are shown in parentheses; otherwise, congruent results were obtained for both strains. $\dagger$ Data from this study.

$\ddagger$ Data from Lai \& Shao (2008).

esterase (C4) and lipase (C14) activities. Furthermore, the inability to hydrolyse Tween 80 and the absence of $\mathrm{N}$ acetyl- $\beta$-glucosaminidase, $\alpha$-chymotrypsin, $\beta$-galactosidase, trypsin and valine arylamidase activities, and the inability to utilize citrate or ethanol as a sole carbon source differentiated strains CL-AP6 ${ }^{\mathrm{T}}$ and CL-AP22 from $P$. xiamenensis (Table 1). The two strains could be differentiated from $P$. pertucinogena by the ability to reduce nitrate, the presence of acid and alkaline phosphatases and esterase lipase (C8) activities, and the inability to utilize succinate as a sole carbon source (Table 1).

The fatty acid methyl esters of whole cells of strains CL$\mathrm{AP} 6^{\mathrm{T}}$ and CL-AP22 were analysed by gas chromatography according to the instructions of the Microbial Identification System (MIDI) at the Korean Culture Center of Micro-organisms (KCCM) in Seoul, Korea. The strains were grown in LB broth at $28{ }^{\circ} \mathrm{C}$ for 2 days. The DNA G $+\mathrm{C}$ content was analysed by HPLC (HP 100; Hewlett Packard) analysis of deoxyribonucleosides as described by Mesbah et al. (1989), after DNA extraction by the method of Marmur (1961). Lambda phage DNA was used as a standard. The isoprenoid quinone composition was determined according to Minnikin et al. (1984) and analysed by HPLC as described by Collins (1985), using Pseudomonas chlororaphis ATCC $9446^{\mathrm{T}}$ (Yamada et al., 1982) as a reference strain.

The fatty acid profiles were similar between strains CL$\mathrm{AP}^{\mathrm{T}}$ and CL-AP22 (Table 2): the major fatty acids of the two strains were $\mathrm{C}_{18: 1} \omega 7 c(40.2-41.6 \%)$, summed feature $3\left(\mathrm{C}_{16: 1} \omega 7 c\right.$ and/or iso- $\left.\mathrm{C}_{15: 0} 2-\mathrm{OH} ; 26.3-26.8 \%\right), \mathrm{C}_{16: 0}$ (13.7-13.9\%) and $\mathrm{C}_{12: 0}(5.8-6.2 \%)$. Other fatty acids are shown in Table 2 . The fatty acids $\mathrm{C}_{18: 1} \omega 7 c$ and $\mathrm{C}_{16: 0}$ were found predominantly in strains CL-AP6 ${ }^{\mathrm{T}}$ and CL-AP22 and related Pseudomonas species (Table 2). However, a significant amount of summed feature 3 was found only in strains CL-AP6 ${ }^{\mathrm{T}}$ and CL-AP22. Furthermore, the absence of fatty acid $\mathrm{C}_{16: 1} \omega 9 c$ clearly differentiated strains CL$\mathrm{AP}^{\mathrm{T}}$ and CL-AP22 from the related Pseudomonas species 
Table 2. Cellular fatty acid contents of strains $C L-A P 6^{\top}$ and CL-AP22 and other phylogenetically related Pseudomonas species

Taxa: 1 , strains CL-AP6 ${ }^{\mathrm{T}}$ and CL-AP22 (data from this study); $2, P$. xiamenensis $\mathrm{C} 10-2^{\mathrm{T}}$ (Lai \& Shao, 2008); 3, P. pertucinogena JCM $11590^{\mathrm{T}}$ (Lai \& Shao, 2008). Unless otherwise indicated, all strains were cultured in LB broth at $28{ }^{\circ} \mathrm{C}$ for 2 days. ND, Not detected; tr, trace amount $(<1 \%)$.

\begin{tabular}{|c|c|c|c|c|}
\hline \multirow[t]{2}{*}{ Fatty acid } & \multicolumn{2}{|l|}{1} & \multirow[t]{2}{*}{2} & \multirow[t]{2}{*}{3} \\
\hline & $\mathbf{L B}^{\star}$ & TSA $\dagger$ & & \\
\hline \multicolumn{5}{|c|}{ Straight-chain fatty acids } \\
\hline $\mathrm{C}_{12: 0}$ & $6.2(5.8)$ & 7.3 & 2.3 & 4.6 \\
\hline $\mathrm{C}_{14: 0}$ & $\operatorname{tr}(\operatorname{tr})$ & $\operatorname{tr}$ & 4.7 & $\operatorname{tr}$ \\
\hline $\mathrm{C}_{15: 0}$ & $\operatorname{tr}(\operatorname{tr})$ & $\operatorname{tr}$ & 2.0 & $\operatorname{tr}$ \\
\hline $\mathrm{C}_{16: 0}$ & $13.7(13.9)$ & 8.4 & 32.5 & 18.8 \\
\hline $\mathrm{C}_{17: 0}$ & $\operatorname{tr}(\operatorname{tr})$ & $\operatorname{tr}$ & 1.6 & $\operatorname{tr}$ \\
\hline $\mathrm{C}_{18: 0}$ & $1.0(1.2)$ & $\operatorname{tr}$ & 5.5 & 8.8 \\
\hline $\mathrm{C}_{17: 0}$ cyclo & $1.7(2.1)$ & 3.8 & $\mathrm{ND}$ & $\mathrm{ND}$ \\
\hline \multicolumn{5}{|c|}{ Unsaturated fatty acids } \\
\hline $\mathrm{C}_{15: 1}$ & $\mathrm{ND}(\mathrm{ND})$ & ND & 1.0 & $\operatorname{tr}$ \\
\hline $\mathrm{C}_{17: 1}$ & $\mathrm{ND}(\mathrm{ND})$ & $\mathrm{ND}$ & 2.5 & $\operatorname{tr}$ \\
\hline $\mathrm{C}_{19: 1}$ & $\mathrm{ND}(\mathrm{ND})$ & $\mathrm{ND}$ & 1.2 & 1.7 \\
\hline $\mathrm{C}_{16: 1} \omega 9 c$ & $\mathrm{ND}(\mathrm{ND})$ & ND & 17.7 & 8.0 \\
\hline $\mathrm{C}_{18: 1} \omega 7 c$ & $41.6(40.2)$ & 40.8 & 17.5 & 52.9 \\
\hline $\mathrm{C}_{18: 1} \omega 9 c$ & $\mathrm{ND}(\mathrm{ND})$ & ND & 6.4 & 1.4 \\
\hline \multicolumn{5}{|l|}{ Hydroxy fatty acids } \\
\hline $\mathrm{C}_{10: 0} 3-\mathrm{OH}$ & $1.8(1.4)$ & 2.8 & $\mathrm{ND}$ & $\mathrm{ND}$ \\
\hline $\mathrm{C}_{12: 0} 3-\mathrm{OH}$ & $3.2(2.8)$ & 3.6 & $\operatorname{tr}$ & $\operatorname{tr}$ \\
\hline $\mathrm{C}_{16: 0} 3-\mathrm{OH}$ & $\mathrm{ND}(\mathrm{ND})$ & ND & 3.6 & $\operatorname{tr}$ \\
\hline Summed feature $3 \ddagger$ & $26.3(26.8)$ & 28.1 & $\mathrm{ND}$ & $\mathrm{ND}$ \\
\hline
\end{tabular}

${ }^{*}$ Data in parentheses were for strain CL-AP22.

$\dagger$ Data were from a different culture condition (TSA with $2 \%$, w/v, $\mathrm{NaCl}$ at $25{ }^{\circ} \mathrm{C}$ for 2 days).

$\ddagger$ Summed feature 3 contains $\mathrm{C}_{16: 1} \omega 7 c$ and/or iso- $\mathrm{C}_{15: 0} 2-\mathrm{OH}$.

(Table 2). The major isoprenoid quinone of strains CL$\mathrm{AP}^{\mathrm{T}}$ and CL-AP22 was Q-9. The genomic DNA G+C contents of strains CL-AP6 ${ }^{\mathrm{T}}$ and CL-AP22 were 59.1 and $57.2 \mathrm{~mol} \%$, respectively. These data support the attribution of strains CL-AP6 ${ }^{\mathrm{T}}$ and CL-AP22 to the genus Pseudomonas (Palleroni, 2005).

Thus, on the basis of the data from the polyphasic taxonomic study, strains CL-AP6 ${ }^{\mathrm{T}}$ and CL-AP22 should be placed in the genus Pseudomonas as representing a novel species, for which the name Pseudomonas pelagia sp. nov. is proposed.

\section{Description of Pseudomonas pelagia sp. nov.}

Pseudomonas pelagia (pe.la'gi.a. L. fem. adj. pelagia of the sea).

Gram-negative, strictly aerobic and motile by a single polar flagellum. Cells are non-spore-forming, straight rod- shaped, approximately $0.4-0.5 \mu \mathrm{m}$ in width and $1.8-$ $2.0 \mu \mathrm{m}$ in length. Cells do not contain poly- $\beta$-hydroxybutyrate granules. No fluorescent pigments are detected. $\mathrm{H}_{2} \mathrm{~S}$ is not produced. After 3 days on LB agar at $25{ }^{\circ} \mathrm{C}$, colonies are circular, convex and white in colour, and about 1.5$2 \mathrm{~mm}$ in diameter. Cells also grow on MA and tryptic soy agar (TSA; Difco). Growth occurs within the temperature range $4-33{ }^{\circ} \mathrm{C}$ (optimum, $25^{\circ} \mathrm{C}$ ) and at $\mathrm{pH}$ 6.5-9.1 (optimum, $\mathrm{pH} 7.5-8.1$ ). Growth occurs in $\mathrm{NaCl}$ concentrations of $0.5-8 \%$, w/v (optimum, 1-2\%). Oxidase and catalase are positive. Positive for amylase and nitrate reductase (a congruent result was obtained in the API 20NE test) activities and degradation of Tweens 20, 40 and 60. Negative for gelatinase activity (a congruent result was obtained in the API 20NE test), hydrolysis of Tween 80, and Voges-Proskauer and methyl red tests. According to API ZYM tests, acid and alkaline phosphatases, esterase (C4), esterase lipase (C8), lipase (C14) and leucine arylamidase activities are positive, but $N$-acetyl- $\beta$-glucosaminidase, $\alpha$-chymotrypsin, cystine arylamidase, $\alpha$-fucosidase, $\alpha$ - and $\beta$-galactosidases, $\alpha$ - and $\beta$-glucosidases, $\beta$ glucuronidase, $\alpha$-mannosidase, trypsin and valine arylamidase activities are negative, and naphthol-AS-BI-phosphohydrolase activity is variable. According to the API 20NE tests, arginine dihydrolase, aesculin hydrolysis, $\beta$-galactosidase, glucose fermentation, indole production and urease are negative. D-Glucose, peptone and pyruvate are utilized as a sole carbon source, but acetate, $N$-acetyl-D-glucosamine, L-arginine, aspartic acid, ascorbate, ethanol, citrate, D-fructose, D-galactose, L-glutamate, glycerol, inositol, lactose, D-mannose, D-ribose, succinate and sucrose are not utilized. Cells are sensitive to ( $\mu \mathrm{g}$ per disc): chloramphenicol (20), gentamicin (6), kanamycin (20) and polymyxin B (25) but resistant to ampicillin (6), cephalexin (20), erythromycin (10), mitomycin C (0.6), nalidixic acid (20), penicillin $G(6)$, streptomycin (6), tetracycline (20) and vancomycin (20). The isoprenoid quinone is Q-9. Major cellular fatty acids are $\mathrm{C}_{18: 1} \omega 7 c$, summed feature 3 $\left(\mathrm{C}_{16: 1} \omega 7 c\right.$ and/or iso- $\left.\mathrm{C}_{15: 0} 2-\mathrm{OH}\right), \mathrm{C}_{16: 0}$ and $\mathrm{C}_{12: 0}$. The DNA G $+C$ content of the type strain is $59.1 \mathrm{~mol} \%$.

The type strain, CL-AP6 ${ }^{\mathrm{T}}\left(=\mathrm{KCCM} 90073^{\mathrm{T}}=\mathrm{JCM} 15562^{\mathrm{T}}\right.$ ), was isolated from a culture of the Antarctic green alga Pyramimonas gelidicola. Strain CL-AP22 (= KCCM 90081), isolated from the same source, is a second strain of the species.

\section{Acknowledgements}

We acknowledge the expert technical support of Ms In-Sung Lee (electron microscopy) of the National Center for Inter-university Research Facilities at Seoul National University. This work was supported by the KOPRI grant No. PE08060 and the BK21 project of the Korean Government.

\section{References}

Altschul, S. F., Gish, W., Miller, W., Myers, E. W. \& Lipman, D. J. (1990). Basic local alignment search tool. J Mol Biol 215, 403-410. 
Anzai, Y., Kudo, Y. \& Oyaizu, H. (1997). The phylogeny of the genera Chryseomonas, Flavimonas, and Pseudomonas supports synonymy of these three genera. Int J Syst Bacteriol 47, 249-251.

Anzai, Y., Kim, H., Park, J.-Y., Wakabayashi, H. \& Oyaizu, H. (2000). Phylogenetic affiliation of pseudomonads based on 16S rRNA sequence. Int J Syst Evol Microbiol 50, 1563-1589.

Bauer, A. W., Kirby, W. M. M., Sherris, J. C. \& Turck, M. (1966). Antibiotic susceptibility testing by a standardized single disk method. Am J Clin Pathol 45, 493-496.

Choi, D. H., Kim, Y.-G., Hwang, C. Y., Yi, H., Chun, J. \& Cho, B. C. (2006). Tenacibaculum litoreum sp. nov., isolated from tidal flat sediment. Int J Syst Evol Microbiol 56, 635-640.

Cole, J. R., Chai, B., Farris, R. J., Wang, Q., Kulam-Syed-Mohideen, A. S., McGarrell, D. M., Bandela, A. M., Cardenas, E., Garrity, G. M. \& other authors (2007). The ribosomal database project (RDP-II): introducing $m y R D P$ space and quality controlled public data. Nucleic Acids Res 35, D169-D172.

Collins, M. D. (1985). Analysis of isoprenoid quinones. Methods Microbiol 18, 329-366.

Englen, M. D. \& Kelley, L. C. (2000). A rapid DNA isolation procedure for the identification of Campylobacter jejuni by the polymerase chain reaction. Lett Appl Microbiol 31, 421-426.

Felsenstein, J. (1981). Evolutionary trees from DNA sequences: a maximum likelihood approach. J Mol Evol 17, 368-376.

Fitch, W. M. (1971). Toward defining the course of evolution: minimum change for a specific tree topology. Syst Zool 20, 406-416.

Guillard, R. R. L. \& Ryther, J. H. (1962). Studies of marine planktonic diatoms. I. Cyclotella nana Hustedt and Detonula confervacea (Cleve). Can J Microbiol 8, 229-239.

Gupta, S. K., Kumari, R., Prakash, O. \& Lal, R. (2008). Pseudomonas panipatensis sp. nov., isolated from an oil-contaminated site. Int J Syst Evol Microbiol 58, 1339-1345.

Hansen, G. H. \& Sørheim, R. (1991). Improved method for phenotypical characterization of marine bacteria. J Microbiol Methods 13, 231-241.

Jeon, Y. S., Chung, H., Park, S., Hur, I., Lee, J. H. \& Chun, J. (2005). jPHYDIT: a JAVA-based integrated environment for molecular phylogeny of ribosomal RNA sequences. Bioinformatics 21, 31713173.

Jukes, T. H. \& Cantor, C. R. (1969). Evolution of protein molecules. In Mammalian Protein Metabolism, vol. 3, pp. 21-132. Edited by H. N. Munro. New York: Academic Press.

Kawai, Y. \& Yabuuchi, E. (1975). Pseudomonas pertucinogena sp. nov., an organism previously misidentified as Bordetella pertussis. Int J Syst Bacteriol 25, 317-323.

King, E. O., Ward, M. K. \& Raney, D. E. (1954). Two simple media for the demonstration of pyocyanin and fluorescin. J Lab Clin Med 44, 301-307.

Kwon, S. W., Kim, J. S., Park, I. C., Yoon, S. H., Park, D. H., Lim, C. K. \& Go, S. J. (2003). Pseudomonas koreensis sp. nov., Pseudomonas umsongensis sp. nov. and Pseudomonas jinjuensis sp. nov., novel species from farm soils in Korea. Int J Syst Evol Microbiol 53, 21-27.

Lai, Q. \& Shao, Z. (2008). Pseudomonas xiamenensis sp. nov., a denitrifying bacterium isolated from activated sludge. Int J Syst Evol Microbiol 58, 1911-1915.

Lane, D. J. (1991). 16S/23S rRNA sequencing. In Nucleic Acid Techniques in Bacterial Systematics, pp. 115-175. Edited by E. Stackebrandt \& M. Goodfellow. Chichester: Wiley.
Lemos, M. L., Toranzo, A. E. \& Barja, J. L. (1985). Modified medium for the oxidation-fermentation test in the identification of marine bacteria. Appl Environ Microbiol 49, 1541-1543.

Liu, C. \& Shao, Z. (2005). Alcanivorax dieselolei sp. nov., a novel alkane-degrading bacterium isolated from sea water and deep-sea sediment. Int J Syst Evol Microbiol 55, 1181-1186.

Marmur, J. (1961). A procedure for the isolation of deoxyribonucleic acid from microorganisms. J Mol Biol 3, 208-218.

Mesbah, M., Premachandran, U. \& Whitman, W. B. (1989). Precise measurement of the $\mathrm{G}+\mathrm{C}$ content of deoxyribonucleic acid by high-performance liquid chromatography. Int J Syst Bacteriol 39, 159167.

Migula, W. (1894). Über ein neues System der Bakterien. Arb Bakteriol Inst Karlsruhe 1, 235-238 (in German).

Minnikin, D. E., O’Donnell, A. G., Goodfellow, M., Alderson, G., Athalye, M., Schaal, A. \& Parlett, J. H. (1984). An integrated procedure for the extraction of bacterial isoprenoid quinones and polar lipids. J Microbiol Methods 2, 233-241.

Ostle, A. G. \& Holt, J. G. (1982). Nile blue A as fluorescent stain for poly- $\beta$-hydroxybutyrate. Appl Environ Microbiol 44, 238-241.

Oyaizu, H. \& Komagata, K. (1983). Grouping of Pseudomonas species on the basis of cellular fatty acid composition and the quinone system with special reference to the existence of 3-hydroxy fatty acids. J Gen Appl Microbiol 29, 17-40.

Palleroni, N. J. (1984). Genus I. Pseudomonas Migula 1894, $237^{\mathrm{AL}}$. In Bergey's Manual of Systematic Bacteriology, vol. 1, pp. 141-199. Edited by N. R. Krieg \& J. G. Holt. Baltimore: Williams \& Wilkins.

Palleroni, N. J. (2005). Genus I. Pseudomonas Migula 1894, $237^{\mathrm{AL}}$ (Nom. Cons., Opin. 5 of the Jud. Comm. 1952, 121). In Bergey's Manual of Systematic Bacteriology, 2nd edn, vol. 2, part B, pp. 323379. Edited by D. J. Brenner, N. R. Krieg, J. T. Staley \& G. M. Garrity. New York: Springer.

Posada, D. \& Crandall, K. A. (1998). modeltest: testing the model of DNA substitution. Bioinformatics 14, 817-818.

Saitou, N. \& Nei, M. (1987). The neighbor-joining method: a new method for reconstructing phylogenetic trees. Mol Biol Evol 4, 406425.

Sambrook, J. \& Russell, D. W. (2001). Molecular Cloning: a Laboratory Manual, 3rd edn. Cold Spring Harbor, NY: Cold Spring Harbor Laboratory.

Skerman, V. B. D. (1967). A Guide to the Identification of the Genera of Bacteria, 2nd edn. Baltimore: Williams \& Wilkins.

Smibert, R. M. \& Krieg, N. R. (1994). Phenotypic characterization. In Methods for General and Molecular Bacteriology, pp. 607-654. Edited by P. Gerhardt, R. G. E. Murray, W. A. Wood \& N. R. Krieg. Washington, DC: American Society for Microbiology.

Sneath, P. H. A., Stevens, M. \& Sackin, M. J. (1981). Numerical taxonomy of Pseudomonas based on published records of substrate utilization. Antonie Van Leeuwenhoek 47, 423-448.

Swofford, D. L. (1998). Phylogenetic analysis using parsimony (PAUP), version 4. Sunderland, MA: Sinauer Associates.

Tamura, K., Dudley, J., Nei, M. \& Kumar, S. (2007). MEGA4: molecular evolutionary genetics analysis (MEGA) software version 4.0. Mol Biol Evol 24, 1596-1599.

Yamada, Y., Takanami-Nakamura, H., Tahara, T., Oyaizu, H. \& Komagata, K. (1982). The ubiquinone systems in the strains of Pseudomonas species. J Gen Appl Microbiol 28, 7-12. 